\title{
Detection of VHSV IVb within the gonads of Great Lakes fish using in situ hybridization
}

\author{
L. Al-Hussinee, J. S. Lumsden* \\ Fish Pathology Laboratory, Department of Pathobiology, Ontario Veterinary College, University of Guelph, Guelph, Ontario,
} N1G 2W1, Canada

\begin{abstract}
Viral haemorrhagic septicaemia virus (VHSV) genotype IVb was recently detected as the cause of numerous mortality events in Great Lakes fish. In situ hybridization was used to examine the gonads from 13 fish, including freshwater drum Aplodinotus grunniens and muskellunge Esox masquinongy that were infected naturally, as well as rainbow trout Oncorhynchus mykiss and fathead minnows Pimphales promelas, which were experimentally infected. Although the ovaries and testes of fish infected by VHSV IVb had few lesions, viral RNA was present in the ovaries of the rainbow trout and fathead minnow and was abundant in the gonads of muskellunge and in the ovaries of freshwater drum. Viral RNA was present mainly surrounding yolk vacuoles/granules or adjacent to the germinal vesicle, with lesser amounts found within the germinal vesicle, in the mesovarium and/or tunica albuginea and blood vessels of the ovary. Viral RNA was also found in and surrounding primary and secondary spermatocytes of the muskellunge.
\end{abstract}

KEY WORDS: Viral haemorrhagic septicaemia virus · VHSV IVb · In situ hybridization · Oocytes

\section{INTRODUCTION}

Viral haemorrhagic septicaemia (VHS) is a disease that causes significant annual economic losses in commercially important wild and cultured fish species worldwide. The VHS virus (VHSV) is an enveloped piscine rhabdovirus with single-stranded ribonucleic acid; it is divided into 4 genotypes that correlate with geographic location (Snow et al. 2004). VHSV is documented to infect more than 50 species of marine or freshwater fish, and VHSV IVb infects at least 28 species of fish in the Great Lakes basin (Winton et al. 2008).

The primary means of transmission is horizontal, and, to date, there is no substantiated evidence for vertical transmission. If vertical transmission were found to occur it could potentially influence regulatory and management options. Following immersion of fertilized trout eggs in water containing VHSV, the virus could be isolated for only a short period afterwards and was not recovered from the hatched fry (Jorgensen 1970). VHSV is present in ovarian fluid (Eaton et al. 1991) but has not been located within the oocyte. We have recently detected VHSV antigen using immunohistochemistry (IHC) from multiple tissues, including mesovarium, testes and oocytes of freshwater drum Aplodinotus grunniens and muskellunge Esox masquinongy collected from Great Lakes mortality events (Al-Hussinee et al. 2011) and in the mesovarium and oocytes of experimentally infected fathead minnows Pimphales promelas (Al-Hussinee et al. 2010). There is a possibility that the polyclonal antibodies used for IHC cross-react with altered host antigens within the oocyte (Al-Hussinee et al. 2010) or that unquenched endogenous peroxidase was present. Therefore, in situ hybridization (ISH) was developed for VHSV $\mathrm{IVb}$ to establish the presence of viral RNA within 
gonadal tissues and oocytes of fish species that were previously confirmed infected with the virus.

\section{MATERIALS AND METHODS}

Tissues. Reproductive tissue was obtained from 6 freshwater drum Aplodinotus grunniens (1 to $5 \mathrm{~kg} ; 6$ ovaries from separate fish) and 2 muskellunge Esox masquinongy (>6 kg; 1 ovary, 1 testis) that were collected from the Bay of Quinte and St. Lawrence River, Canada, respectively, during mortality events associated with VHSV IVb (Lumsden et al. 2007, Al-Hussinee et al. 2011). Tissues from rainbow trout Oncorhyncus mykiss ( 15 g) and fathead minnow Pimphales promelas $(\sim 10 \mathrm{~g})$ were collected from fish following experimental infection with VHSV IVb (Al-Hussinee et al. 2010). Relatively few gonads from rainbow trout ( $\mathrm{n}=2 ; 1$ infected and 1 control) and fathead minnow ( $\mathrm{n}=3 ; 2$ infected and 1 control) were available for sectioning. Pooled tissues including gonads were subjected to virus isolation and reverse-transcriptase polymerase chain reaction (RT-PCR) (Al-Hussinee et al. 2010). Tissues were fixed in $10 \%$ neutral buffered formalin, were sectioned by routine methods, and IHC for viral antigen was performed on all tissues (Al-Hussinee et al. 2010). For the present study, additional liver, heart and gonads were subjected to IHC to allow comparison of the pattern of viral antigen with viral RNA detected using ISH, as described below. All tissues used in the present study were from fish that were confirmed infected with VHSV IVb by virus isolation, RTPCR and IHC.

In situ hybridization. All glassware used for in situ hybridization was cleaned and rinsed for $1 \mathrm{~h}$ with certified 0.25 M NaOH (Fisher Scientific) and then rinsed in diethylpyrocarbonate (DEPC; Sigma) water, airdried, and left until used. Reagents and buffers used for ISH were made with RNase-free DEPC water.

For labelling VHSV RNA, an isolate from freshwater drum (U13653, Lumsden et al. 2007) was replicated in epithelioma papulosum cyprini cells. Upon appearance of cytopathic effects, the culture supernatant was used to amplify the template, using RT-PCR with VHSV IVb-specific primers (Al-Hussinee et al. 2010). The template obtained was labelled with digoxigenin (DIG) (Roche) with the labelling procedure and thermocycling conditions recommended by the manufacturer. Briefly, primary denaturation was performed at $95^{\circ} \mathrm{C}$ for $1 \mathrm{~min}$, followed by 40 cycles at 95,60 and $72^{\circ} \mathrm{C}$ for $30 \mathrm{~s}, 30 \mathrm{~s}$ and $40 \mathrm{~s}$, respectively. A final elongation cycle was performed at $72^{\circ} \mathrm{C}$ for $7 \mathrm{~min}$. To determine whether the probe had been successfully labelled, $5 \mu \mathrm{l}$ of labelled and negative control (unlabelled) mixtures were electrophoresed using $1.2 \%$ agarose gels, and bands were visualized using ultraviolet light. The DIGlabelled and unlabelled probes were each aliquoted and saved at $-20^{\circ} \mathrm{C}$ until used.

ISH was performed on selected tissues, including heart and liver, from fish that had moderate to severe histological lesions and also from ovary (all species) and testes (muskellunge only) in which VHSV IVb antigen had been detected by IHC (Al-Hussinee et al. 2011). ISH was performed as described (Sur et al. 2003) with some modifications, as described below.

Deparaffinized tissue sections: Unstained $5 \mu \mathrm{m}$ sections were cut from paraffin blocks and heated at $60^{\circ} \mathrm{C}$ for $45 \mathrm{~min}$; this was followed by double dewaxing in xylene for 5 min followed by a graded series of ethanol $(100,95,80$ and $50 \%$ twice each for $1 \mathrm{~min})$. Sections were rinsed in DEPC water for $1 \mathrm{~min}$ and transferred into humidified chambers and/or a water bath.

Prehybridization and hybridization: After washing the sections with phosphate-buffered saline (PBS) (1.37 M NaCl, $0.001 \mathrm{M} \mathrm{KH}_{2} \mathrm{PO}_{4}, 0.01 \mathrm{M} \mathrm{Na}_{2} \mathrm{HPO}_{4}$, $0.002 \mathrm{M} \mathrm{KCl}$ in $\mathrm{DEPC}_{i} \mathrm{pH} 8.2$ ) for $5 \mathrm{~min}$, tissues were digested with Proteinase K (Qiagen; prepared just prior to use) at a final concentration $100 \mu \mathrm{g} \mathrm{ml}^{-1}$ in PBS for $15 \mathrm{~min}$ at $45^{\circ} \mathrm{C}$. Tissue sections were re-fixed in $0.4 \%$ paraformaldehyde (SPI Supplies) buffered in PBS for 5 min at room temperature (RT). Sections were then covered with pre-hybridization buffer. The prehybridization buffer $(25.5 \mathrm{ml})$ was prepared as follows: $5 \mathrm{ml} 20 \times$ standard saline citrate (SSC), $12.5 \mathrm{ml} \mathrm{100 \%}$ formamide, $0.5 \mathrm{ml} 50 \times$ Denhardt's solution and $5 \mathrm{ml}$ $25 \%$ dextran sulfate (all USB Corp.); $2.5 \mathrm{ml}$ salmon sperm DNA (10 $\mathrm{mg} \mathrm{ml}^{-1}$; Invitrogen) was boiled and added to the pre-hybridization buffer, which was stored at $4^{\circ} \mathrm{C}$ until used. The sections were covered with pre-hybridization buffer for $1 \mathrm{~h}$ at $45^{\circ} \mathrm{C}$. DIGlabelled and unlabelled probe was diluted 1:200 in pre-hybridization buffer, heated at $95^{\circ} \mathrm{C}$ for $10 \mathrm{~min}$, and then chilled on ice until used. Sections were then washed briefly with $2 \times \mathrm{SSC}$, and covered by DIGlabelled probe at $45^{\circ} \mathrm{C}$ overnight.

Post-hybridization: Tissues were washed sequentially, twice each, with $2 \times, 1 \times$ and $0.5 \times \mathrm{SSC}$ at $45^{\circ} \mathrm{C}$ for $25 \mathrm{~min}, 5 \mathrm{~min}$ and $5 \mathrm{~min}$, respectively, followed by 5 min washing with buffer A (1 M Tris base and $1.5 \mathrm{M}$ $\mathrm{NaCl}$ in $\mathrm{DEPC}_{i} \mathrm{pH}$ 7.5). Tissue sections were then covered by buffer B (0.25 g blocking reagent [Roche] in $50 \mathrm{ml}$ of maleic acid buffer, $0.15 \mathrm{M}$ maleic acid [Sigma], $0.1 \mathrm{M} \mathrm{NaCl}$ in DEPC water; $\mathrm{pH} 7.5$ ) at $45^{\circ} \mathrm{C}$ for $20 \mathrm{~min}$. The sections were then incubated with anti-DIG alkaline phosphatase conjugate (Roche), diluted 1:1000 in buffer $\mathrm{B}$, for $1 \mathrm{~h}$ at $45^{\circ} \mathrm{C}$. After washing the tissues with buffer A and buffer $\mathrm{C}(0.1 \mathrm{M}$ Tris base, $0.1 \mathrm{M} \mathrm{NaCl}$ in $\mathrm{DEPC}_{i} \mathrm{pH}$ 8.0) for $10 \mathrm{~min}$ each at RT, sections were incubated overnight in the dark at RT with development solution $(9: 1 \mathrm{v} / \mathrm{v}$ buffer $\mathrm{C}$ and $10 \%$ polyvinyl 
alcohol [Sigma] mix; 49:1 v/v development solution and NBT-BCIP (nitro-blue tetrazolium chloride-5bromo-4-chloro-3'-indolyphosphate $p$-toluidine salt [Roche]). The reaction was then stopped by washing tissue sections with buffer $\mathrm{D}(0.01 \mathrm{M}$ Tris base and $0.001 \mathrm{M}$ EDTA $\cdot 2 \mathrm{H}_{2} \mathrm{O}$ [disodium salt] in DEPC; $\mathrm{pH}$ 8.0) at RT for $15 \mathrm{~min}$, counterstained with $1 \%$ aqueous eosin-Y for $10 \mathrm{~min}$, and mounted.

Controls: With every ISH run we used a set of control slides, including dual negative controls and a single positive control. Negative controls consisted of an unlabelled probe used with VHSV IVb-infected tissue and a labelled probe used with various known uninfected tissues (including ovary from fathead minnows and rainbow trout). The positive control used labelled probe on VHSV IVb-infected tissues.

\section{RESULTS}

The product size of VHSV IVb by RT-PCR was 558 bp. DIG labelling success was determined by agarose electrophoresis, after which the size of the probe was approximately 100 bp higher (not shown).

In the pathological examination of all 4 species of fish, we found gross lesions and lesions detected by light microscopy in several parenchymal organs that were consistent with VHS (Lumsden et al. 2007, AlHussinee et al. 2010). However, there were no lesions present in the ovary or testes of these species.

Viral antigen was detected using IHC in numerous tissues (Al-Hussinee et al. 2010, 2011), including the myocardium (Fig. 1) and blood vessels (Figs. 2 \& 3), as well as gonadal tissues. Tropism for endothelium is characteristic of VHSV (Al-Hussinee et al. 2010) and this was particularly notable in gonadal blood vessels, in which numerous leukocytes were also strongly positive (not shown). Viral antigen was also observed in the mesovarium and tunica albugina as well as in the germinal vesicle and yolk vacuole/granules of oocytes (Fig. 2).

ISH was performed on the heart and liver to demonstrate that the same tissue patterns were found when IHC was used (Figs. 1 \& 3). VHSV IVb RNA was detected (dark blue to black staining) in the myocardium (Fig. 4) and hepatic blood vessels (Fig. 5) of freshwater drum. Multifocally in the myocardium, there was abundant staining in single cells or patches of cells (Fig. 4). Viral RNA was predominantly present in the endothelium, but was also found in the intima and media of hepatic venules that were markedly thickened and elevated by oedema (Fig. 5).

VHSV IVb RNA detected by ISH in gonadal tissue of muskellunge (1 ovary and 1 testis) was abundant. Scattered viral RNA was present within oocytes of muskel-

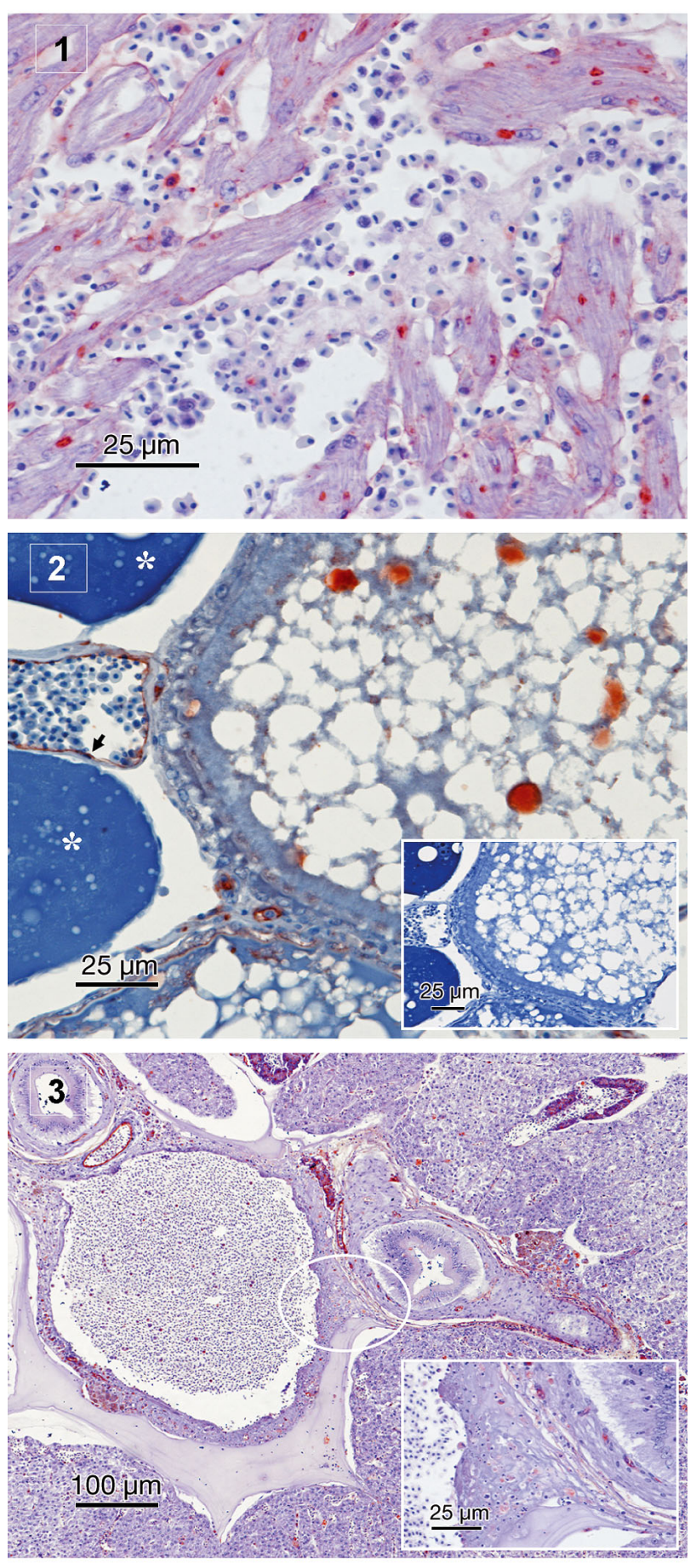

Figs. 1 to 3. Freshwater drum Aplodinotus grunniens infected by VHSV IVb. Immunohhistochemistry (IHC) with haematoxylin counterstain. Fig. 1. Heart tissue. Cardiac myofibres with multifocal cytoplasmic immunopositive staining. Fig. 2. Ovary. Maturing oocytes that contain copious immunopositive material, in contrast to the undeveloped oocytes $(*)$. Vascular endothelium (arrow) is prominently stained as well. Inset: Pre-immune rabbit serum replaced rabbit-anti-VHSV. Fig. 3. Liver. Viral antigen is present within the thickened

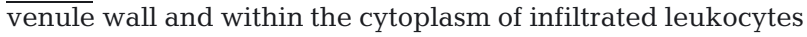
(magnified in inset) 

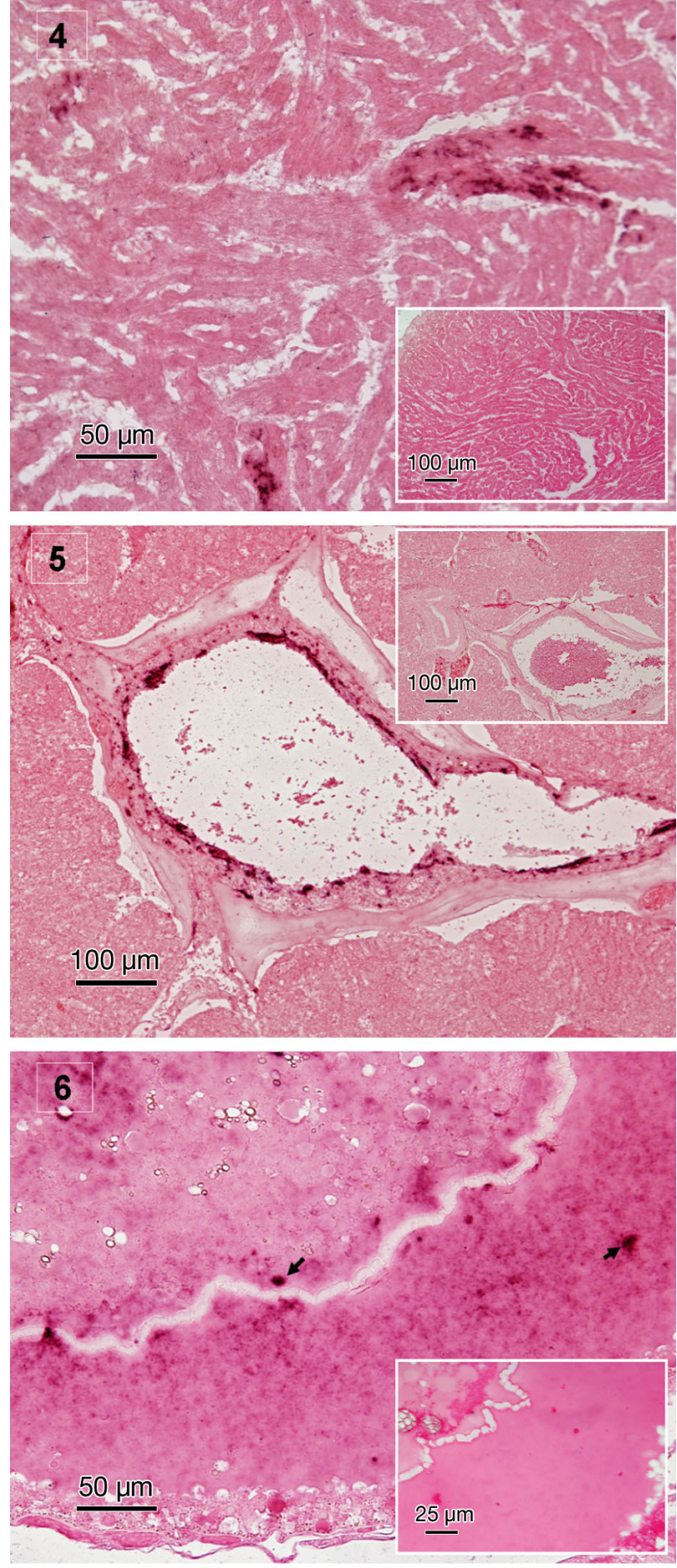

Figs. 4 to 6. Great Lakes fish species infected with VHSV VIb. In situ hybridization (ISH) with eosin-Y counterstain (insets: ISH with unlabelled probe). Fig. 4. Heart of a freshwater drum Aplodinotus grunniens. Multifocal staining of myofibres for VHSV RNA. Fig. 5. Liver of a freshwater drum A. grunniens. Hepatic venule contains endothelial and mural VHSV RNA. Fig. 6. Ovary of a muskellunge Esox masquinongy. Mature oocyte that has VHSV RNA throughout the oviplasm and, to a lesser extent, in the germinal vesicle (arrows) lunge, and was found mainly surrounding cytoplasmic yolk vacuoles/granules of oocytes, but also in the germinal vesicle (Fig. 6) and, to a lesser extent, in connective tissue of the mesovarium where the endothelial cells of blood vessels were also positive (not shown). Abundant multifocal staining for viral RNA was detected in, and surrounding testicular primary and secondary spermatocytes (Fig. 7) while the interstitium and blood vessels were not stained.

Five of 6 ovaries examined from freshwater drum contained viral RNA. Most mature oocytes had moderate, multifocal staining, found mainly surrounding cytoplasmic yolk vacuoles/granules, while maturing oocytes also contained cytoplasmic viral RNA (Fig. 8). However, the majority of staining was present in either degenerative or atretic oocytes (not shown). Mild to moderate staining was identified in the mesovarium.
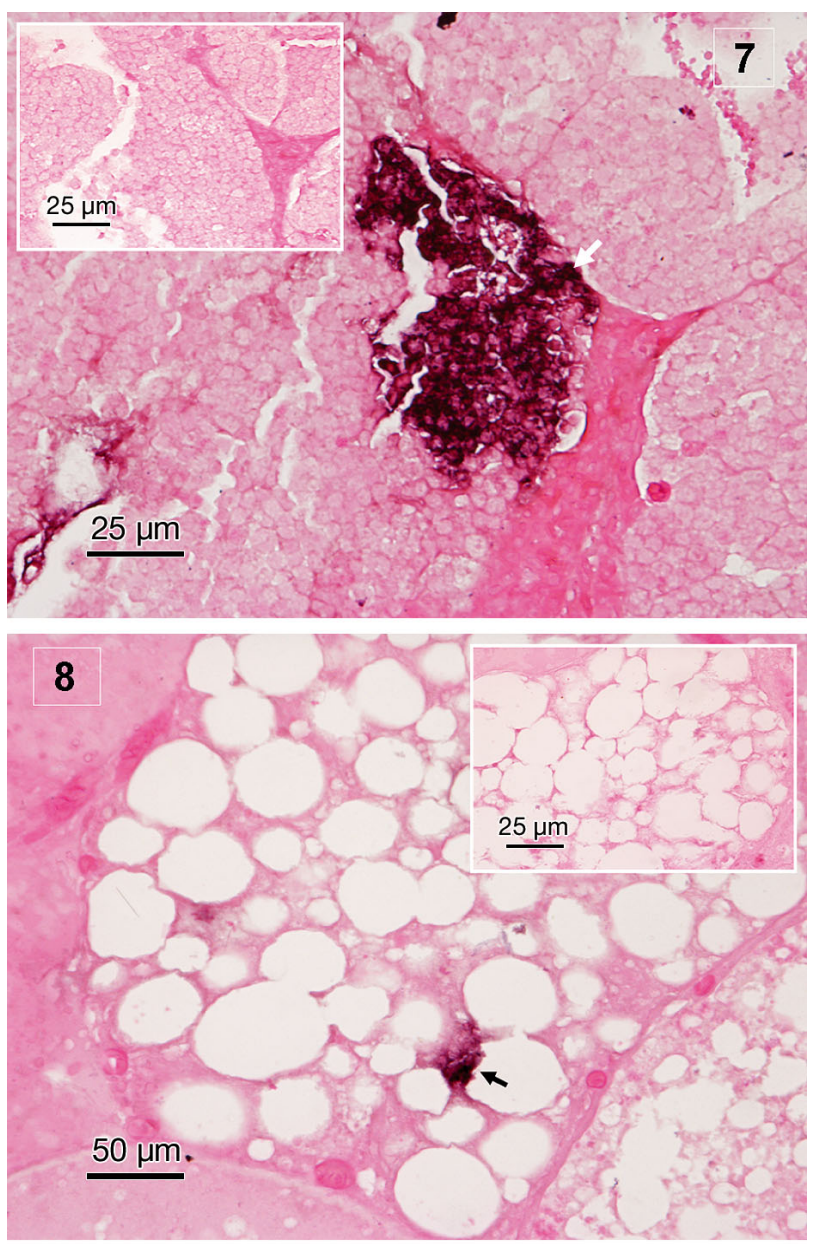

Figs. 7 \& 8. Great Lakes fish species infected with VHSV VIb. In situ hybridization (ISH) with eosin-Y counterstain (insets: ISH with unlabelled probe). Fig. 7. Testis of a muskellunge Esox masquinongy. Clusters of spermatocytes contain VHSV RNA. Fig. 8. Ovary of a freshwater drum Aplodinotus grunniens. VHSV RNA is present in a maturing oocyte (arrow) 
Two of 3 ovaries examined from fathead minnows contained viral RNA. In those ovaries that were positive, few mature oocytes contained viral RNA, and staining was light, but it was present within the vitelline envelope (chorion) and in the oviplasm (Fig. 9) and, to a lesser extent, adjacent to and within the germinal vesicle. However, viral RNA was not detected in the mesovarium (not shown).

In the single rainbow trout ovary that was positive, abundant staining was present in the mesovarium, with lesser amounts in both the oviplasm and germinal vesicles of immature oocytes (Fig. 10). No VHSV IVb RNA was detected in known negative tissues when the labelled probe was used, and no signal was present when VHSV IVb-positive tissues were incubated with unlabelled probe.

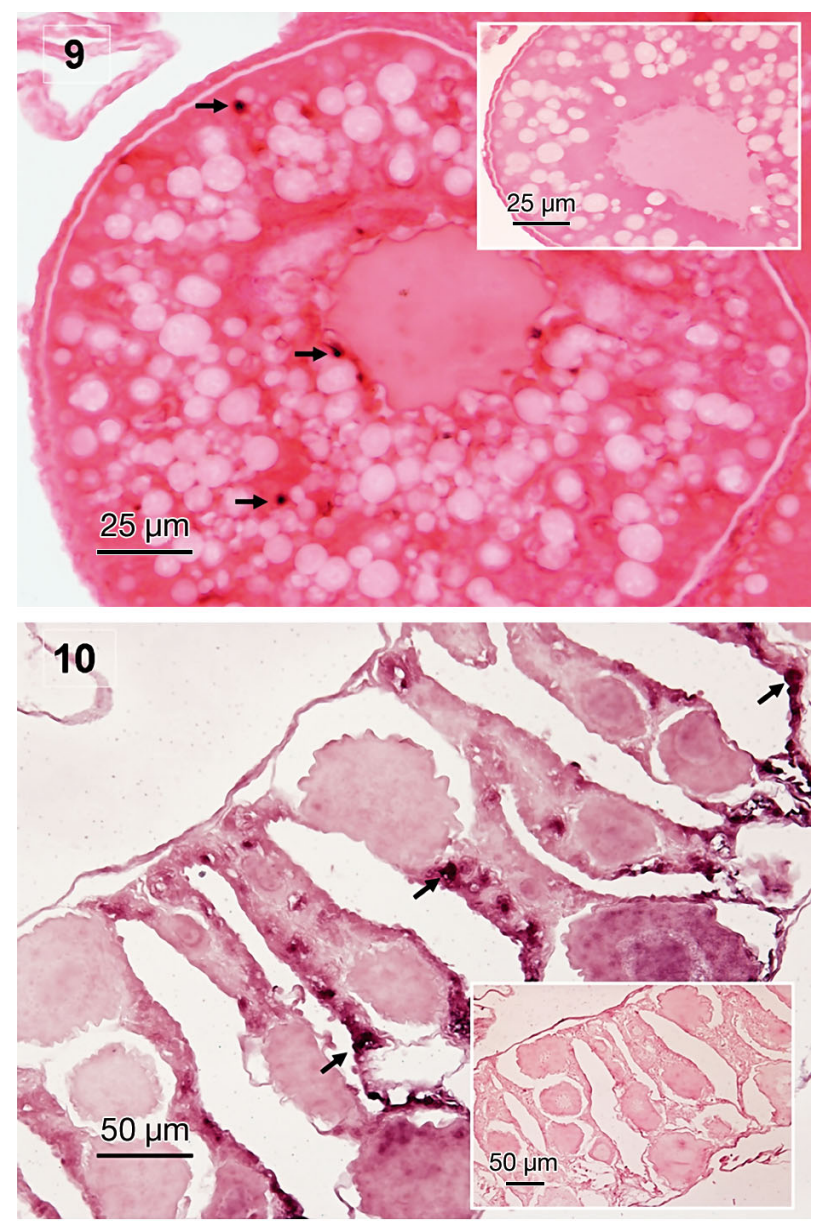

Figs. 9 \& 10. Great Lakes fish species experimentally infected with VHSV VIb 17 d previously. In situ hybridization (ISH) with eosin-Y counterstain (insets: ISH of uninfected fish with labelled probe). Fig. 9. Ovary of a fathead minnow Pimphales promelas. Mature oocyte contains VHSV RNA adjacent to the germinal vesicle and in the yolk granules (arrows). Fig. 10. Immature ovary of a rainbow trout Oncorhyncus mykiss. VHSV RNA is most prominent in the mesovarium (arrows) and immature oocytes

\section{DISCUSSION}

VHSV IVb antigen was previously identified using IHC in the heart and liver, among other tissues, and in the endothelium of blood vessels of several species of infected fish (Al-Hussinee et al. 2011). Viral antigen was also found in ovaries and testes from muskellunge E. masquinongy and ovaries from freshwater drum A. grunniens collected from Great Lakes mortality events (Al-Hussinee et al. 2011) and from experimentally infected fathead minnows $P$. promelas (Al-Hussinee et al. 2010). Using ISH in the present study, viral RNA was detected inside the oocytes of these 3 species of fish and in the immature oocytes of experimentally infected rainbow trout O. mykiss. The distribution of VHSV RNA in the myocardium and liver correlated with the distribution of VHSV antigen detected by IHC (Al-Hussinee et al. 2010, 2011).

While IHC, ISH and RT-PCR are widely used for detecting virus in tissues, ISH is highly sensitive (Henke et al. 2006) and allows for some discrimination of tissue morphology. Detection of viral nucleic acid in formalin-fixed tissues using ISH is routine (NadinDavis et al. 2003, Sur et al. 2003); however, this technique has not previously been performed for VHSV. The greater sensitivity of ISH compared with IHC (Sur et al. 2003) is a likely reason why we did not detect viral antigen in oocytes of experimentally infected rainbow trout (Al-Hussinee et al. 2010) but did detect the presence of viral RNA using ISH.

Evidence to date suggests that vertical transmission does not occur with VHSV. The virus has been found in ovarian fluid and in milt (Eaton et al. 1991); however, VHSV did not adsorb to Chinook salmon sperm, unlike infectious haematopoietic necrosis virus (Mulcahy \& Pascho 1984). VHSV wasn't isolated from the fry of naturally infected trout or from trout eggs that had been immersed in VHSV (Jorgensen 1970). In addition, naturally infected turbot Psetta maxima did not produce infected fry as determined by virus isolation or RT-PCR (Nishizawa et al. 2006). Because VHSV is present in the oocytes of at least some infected fish, as determined in the present study, antiviral factors within yolk components could inactivate virus and/or interrupt replication (Wang et al. 2008). Should the intra-oocytic virus survive for a period, infected eggs still might not have been fertilized, as many in the present study appeared to be undergoing degeneration, at least in the freshwater drum. Certainly, established biosecurity/sanitary measures that involve egg disinfection and/or screening of broodstock greatly reduce the practical risk of vertical transmission should it actually occur (Amos et al. 1998). 
Acknowledgements. The Fish Pathology Laboratory is part of the Canadian Cooperative Wildlife Health Centre (CCWHC) and received funding for this study from Fisheries and Oceans Canada via the Aquaculture Collaborative Research and Development Program and the Natural Sciences and Engineering Research Council. L.A.H. is a recipient of an Ontario Veterinary College fellowship. Thanks to the Royal Botanic Gardens, Burlington, Ontario, for allowing fish to be collected from Cootes Paradise and to Ontario Ministry of Natural Resources staff and L. Shirose of the CCWHC for collecting fish. Thanks to S. Russell for review of the manuscript.

\section{LITERATURE CITED}

Al-Hussinee L, Huber P, Russell S, LePage V and others (2010) Viral haemorrhagic septicaemia virus IVb experimental infection of rainbow trout, Oncorhynchus mykiss (Walbaum), and fathead minnow, Pimphales promelas (Rafinesque). J Fish Dis 33:347-360

Al-Hussinee L, Lord S, Stevenson RMW, Casey RN and others (2011) Immunohistochemistry and pathology of viral hemorrhagic septicemia virus, type IVb associated with mortality in multiple Great Lakes fish. Dis Aquat Org 93:117-127

Amos K, Thomas J, Hopper K (1998) A case history of adaptive management strategies for viral hemorrhagic septicemia virus (VHSV) in Washington State. J Aquat Anim Health 10:152-159

Eaton WD, Hulett J, Brunson R, True K (1991) The first isolation in North America of infectious hematopoietic necrosis virus (IHNV) and viral hemorrhagic septicemia virus (VHSV) in coho salmon from the same watershed. J Aquat Anim Health 3:114-117

Henke RT, Eun Kim S, Maitra A, Paik S, Wellstein A (2006) Expression analysis of mRNA in formalin-fixed, paraffin-

Editorial responsibility: Mark Crane, Geelong, Victoria, Australia embedded archival tissues by mRNA in situ hybridization. Methods 38:253-262

Jorgensen PE (1970) The survival of viral hemorrhagic septicemia (VHS) virus associated with trout eggs. Riv Ital Piscic Ittiopatol 5:13-14

Lumsden JS, Morrison B, Yason C, Russell S and others (2007) Mortality event in freshwater drum Aplodinotus grunniens from Lake Ontario, Canada, associated with viral haemorrhagic septicemia virus, Type IV. Dis Aquat Org 76:99-111

> Mulcahy D, Pascho RJ (1984) Adsorption to fish sperm of vertically transmitted fish viruses. Science 225:333-335

> Nadin-Davis SA, Sheen M, Wandeler AI (2003) Use of discriminatory probes for strain typing of formalin-fixed, rabies virus-infected tissues by in situ hybridization. J Clin Microbiol 41:4343-4352

Nishizawa T, Savas H, Isidan H, Ustundag C, Iwamoto $H$, Yoshimizu M (2006) Genotyping and pathogenicity of viral hemorrhagic septicemia virus from free-living turbot (Psetta maxima) in a Turkish coastal area of the Black Sea. Appl Environ Microbiol 72:2373-2378

Snow M, Bain N, Black J, Taupin V and others (2004) Genetic population structure of marine viral haemorrhagic septicemia virus (VHSV). Dis Aquat Org 61:11-21

> Sur JH, Allende R, Doster AR (2003) Vesicular stomatitis virus infection and neuropathogenesis in the murine model are associated with apoptosis. Vet Pathol 40:512-520

Wang Z, Zhang S, Wang G, An Y (2008) Complement activity in the egg cytosol of zebrafish Danio rerio: evidence for the defense role of maternal complement components. PLoS ONE 3:e1463

Winton JR, Kurath G, Batts WN (2008) Molecular epidemiology of viral hemorrhagic septicemia virus in the Great Lakes region. US Geological Service fact sheet, 20083003. USGS, Washington, DC

Submitted: August 2, 2010; Accepted: January 18, 2011 Proofs received from author(s): May 15, 2011 